\title{
RECONSTRUCTION THE MEANING OF INTENTION TOWARDS BEHAVIORAL CHANGE IN ISLAMIC PSYCHOLOGICAL PERSPECTIVES
}

\author{
Sutipyo Ru'iya \\ Department of Islamic Education, Faculty of Islamic Religion, \\ Universitas Ahmad Dahlan \\ Kapas Street No. 9 Yogyakarta, D.I Yogyakarta, Indonesia. 55166 \\ Email: sutipyo@pai.uad.ac.id
}

\begin{abstract}
Aligning intentions in the Islamic view is a must because whether or not human deeds are accepted depends on their intentions. This article highlights how intentions from an Islamic perspective and how intentions arise from a psychological perspective. This research is librarian research that collects data by reading books, journals, and several relevant documents to the theme of the study. The data were obtained, then analyzed, analyzed, compared, then took the topics and cited them. According to the Islamic view, the results showed that the Intention is very urgent and should rest for the value of dedication to Allah. A sincere intention, because of Allah, will add extra strength to someone to do a job. Meanwhile, according to psychology, Intention is influenced by three things: attitude toward control, subjective norms, and perceived behavior control. The article concludes that the Intention is influenced by two things, the earthly and religious elements. Man's motivation to do work is what colors his Intention, whether for the world or the hereafter.
\end{abstract}

Keywords: attitude, perceived behavior control, religiosity, subjective norms

\begin{abstract}
Abstrak: Menyelaraskan niat dalam pandangan Islam adalah suatu keharusan, karena diterima atau tidaknya perbuatan manusia tergantung pada niatnya. Artikel ini menyoroti bagaimana niat dari sudut pandang Islam dan bagaimana niat muncul dari perspektif psikologis. Penelitian ini adalah penelitian kepustaan, yang mengumpulkan data dengan cara membaca buku-buku, jurnal dan beberapa dokumen yang relevan dengan tema kajian. Data yang diperoleh, lalu ditelaah, dianalisis, dikomparasikan, kemudian ambil kesamaan topiknya dan disimpulkan. Hasil penelitian menunjukkan bahwa menurut pandangan Islam, niat itu sangat mendesak dan harus bertumpu pada nilai pengabdian kepada Allah. Niat yang tulus karena Allah, akan menambah kekuatan ekstra seseorang untuk melakukan suatu pekerjaan. Sedangkan menurut psikologi intensi dipengaruhi oleh tiga hal yaitu sikap terhadap kontrol, norma subjektif, dan kontrol perilaku yang dipersepsikan. Artikel tersebut menyimpulkan bahwa niat tersebut dipengaruhi oleh dua hal, yaitu unsur duniawi dan unsur religius. Motivasi manusia untuk bekerja itulah yang mewarnai niatnya, baik untuk dunia maupun akhirat.
\end{abstract}

Kata Kunci: kontrol perilaku persepsian, norma subjektif, religiusitas, sikap

\section{Introduction}

Talking about Intention, it will be closely related to human behavior. Humans will never be separated from certain behaviors throughout their life, whether the behavior is wanted or "forced" to do. According to Islamic teachings, a person's behavior/actions are preceded by Intention. This is stated in a hadith narrated by Bukhari in Sahihnya no hadith 52:

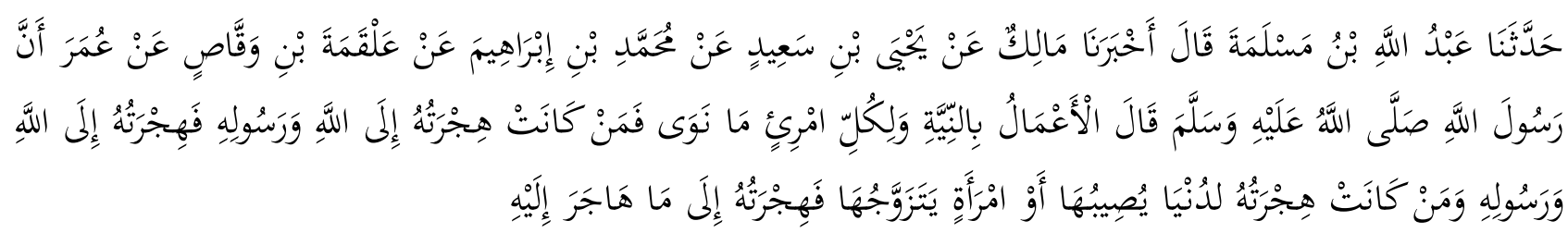

Meaning:

Having told us Abdullah bin Maslamah said, had narrated us, Malik, from Yabya bin Sa'id from Mubammad bin Ibrahim from Alqamah bin Waqash from Umar, that the Messenger of Allah-peace and prayer of Allah be upon bim said: "All actions depend on the Intention, and (retribution) for each person (depending) on what they intend to do; 
whoever wants to move because of Allah and His Messenger, then the migration is to Allah and His Messenger. to what he was designed to be." (Narrated by Bukhari) (Rajab, 2006).

This paper will discuss why a person must reconstruct his Intention so that all his actions are of good value, both in front of humans, especially before Allah SWT. In every human behavior, Goodwill will launch his actions so that the move will be completed properly. Behavior that is intended for goodwill produces good; likewise, behavior designed for bad will gain evil. This paper will not discuss Intention from the perspective of fiqh. Still, it will describe the meaning of Intention from a language perspective and terms that will be dissected with the knife of psychological analysis. Psychological analysis is needed because the process of intent is filled with the psychological dynamics before they act.

The psychological theory that talks about Intention is the theory presented by Icek Ajzen and is known as the Theory of Planned Behavior (TRA) (Ajzen, 1991). This theory will complement the discussion of Intention, according to the views of previous scholars, which will be combined with several psychological theories as above.

\section{Materials and Methods}

This study uses a library research method. Studies literature is an activity of reading and writing to collect data, and then the data is processed as material in research (Idrus, 2009). Idrus further explained four characteristics in the literature study method: first, the researcher takes information not from the field but text or writing. Second, the library data is "ready to use" because the researcher takes data from the text, not from the field. Third, library data is secondary, meaning that the data is obtained second-hand, not data from the original field. Fourth, library data can be obtained at any time because it is not limited by time and space.

The method of collecting data used in this research is to read several scientific works, such as journals, textbooks, and various documents that are considered relevant (Purwanto, 2010). Then the data is reviewed, analyzed, and even compared, then summarized and written in the form of scientific papers.

\section{Result and Discussion}

\section{A. Asbabul Wurud Hadith}

This was because when the Prophet migrated from Mecca to Medina, there was a man who initially did not want to emigrate. This man had a lover named Umm Qais who joined the Prophet in the migration. The man who loved him then knew that Umm Qais migrated with the Prophet. Because the man loved Umm Qais and wanted to marry her, he finally emigrated to marry the woman he idolized ('Ted, 2002). According to Ibn Dihyah, the woman's name was Qaiah (Al-Asqalani, 2008).

This incident was conveyed to Rasulullah SAW by a friend of the man who migrated, and the friend asked about the status of the man who had moved because he "chased" the woman he liked. This hadith is the Prophet's answer to his friend's question about the status of a man who emigrated because he pursued the woman he wanted to marry.

\section{B. Meaning of Intentions, Perspective Language, and Terms}

\section{The Intentions of the Arabic Perspective}

When Arabs use the word niyat, it means a goal (al-qashd). In Arabic, Lisanul between an-niyyat and an-nawa has the same meaning. Meanwhile, niyat is the female form of nawa. Therefore, when they say: "Nawa asy-syai'a (someone has led to something), yanwibi niyyatan wa niyatan. Intawabu sentence, meaning he's headed to something. When the Arabs say nawaka allabu bi al khair, Allah will give you a good goal and lead you to that goal

From various points of view of language, Sulaiman Al-Asyqar concluded that an-niyat is used as a goal, or Intention is the goal where someone leads to that place. Besides that, Intention is also interpreted as something that accompanies the goal (Al-Asyqar, 2010). Meanwhile, in Misbah Al- 
Munir's book, the word intention is also defined as al-azm or desire. It means that Intention is a desire devoted to a job so that it has a strong desire from the heart to complete the job.

2. Intention Perspective of Terms

According to the term, Intention has many meanings, which will be described as follows (AlAsyqar, 2010):

a. The meaning of Intention is desire (al-'Azm) and goal (al-Qashd)

Imam Nawawi said that Intention is to lead to something and desire to do it. The Qurafi also says that Intention is a goal a person has set in his heart so that he wishes to work on it. Meanwhile, al-Khithabi said that Intention is a person's goal towards something, which according to his heart's desire, that person must follow up.

From the description above, it can be concluded that the goals and desires are part of the Intention. Meanwhile, Ibnul Qayyin al-Jauzi argues that intentions and goals have differences. First, goals are closely related to the work that can be done by himself and others. Meanwhile, the Intention is only related to the work that the person himself will do. Second, goals only apply to work that is capable of being done. Meanwhile, Intention can be used to work that is impossible or difficult to do.

b. The meaning of Intention is will (al-iradab)

Ad-Daraz defines Intention as a movement in which a person will pursue his will by doing something he wants. This opinion was reinforced by al-Jirhani, who said that a wish could ensure a choice.

c. The meaning of Intention is sincere

Some scholars interpret intentions as sincere, but others are reluctant to interpret them sincerely. The reason for those who are unwilling is because sincerity is part of the Intention; sincerity is also part of the nature of the Intention. Sincerity is an intention that is entrusted only to Allah and not to others.

d. The meaning of Intention is an act and desire of the heart

This definition is a conclusion from some of the previous descriptions, as conveyed by Hakim al-Baidhawi, that Intention is an expression of a person's vibrations towards a phenomenon that is related to his goal so that he is determined to take the benefit or avoid the risks that will befall him, both risks in the form of treasure and time.

Seeing the meaning of Intention from the two points of view above, both have very similar meanings. Intention means someone's will and desire for something, so that person has the choice to earn that desire sincerely to do so to gain the pleasure of Allah SWT.

3. The Intention in a Psychological Perspective

To discuss human behavior, the theory of psychology can use the Theory of Planned Behavior (TPB), a refinement of the Theory of Reasoned Action (TRA). The theory of reasoned behavior (TRA) says that human behavior is influenced by one's intentions (Ajzen \& Fishbein, 1973). Meanwhile, Intention is influenced by three things, namely attitude toward the control, subjective norms. This theory was then developed again into the dependent behavior theory (TPB), where the variables were added with other commands that affect behavioral interest, namely perceived behavioral control, which is a condition that makes it easy or difficult for someone to do something. According to Ajzen (1991), the central authority of individual behavior is that the behavior is influenced by the individual's Intention (control intention) of this particular behavior (Sulaeman, 2016). More clearly for the TPB model can be seen in the Figure 1. 


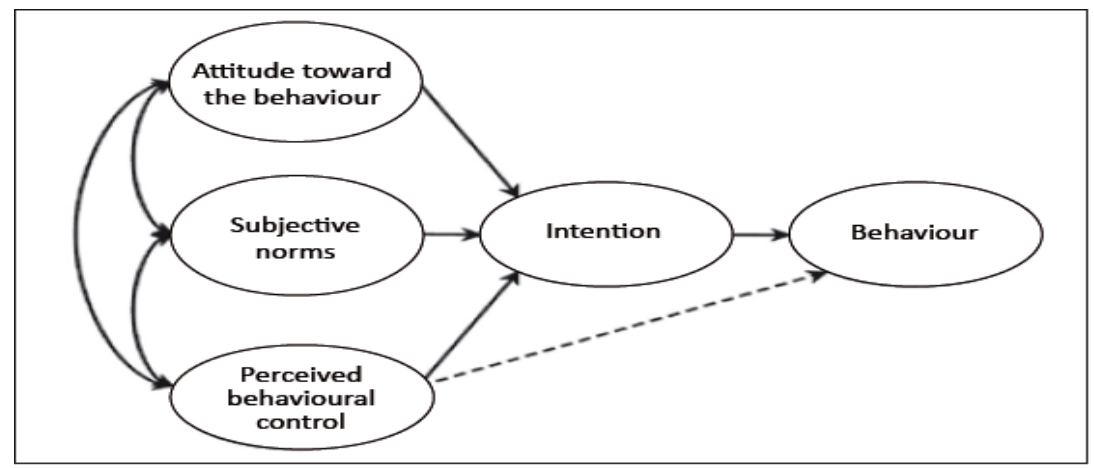

Figure 1. Theory of Planned Behavior (TPB) model

The above chart can be explained in the following description.

a. Attitude toward the control

Attitude is a positive or negative evaluation of particular objects, people, institutions, events, behaviors, or interests. The individual's attitude towards a behavior is derived from the belief in the consequences that the behavior itself will cause. Therefore, attitudes consist of three essential components, namely: a) cognitive, which is a representation of what individuals believe in, which can be in the form of perceptions, beliefs, stereotypes about something, b) affective, which is the individual's feelings towards an object related to the problem. Emotion, c) conative, is a behavior component in an attitude structure that shows how the behavior or tendencies to behave in a person are related to the object of the attitude he faces.

b. Subjective norms

Subjective norms are perceptions of existing social pressures, then require someone to consider whether or not to do behavior related to perceived normative decisions from that behavior. Subjective norms describe the extent to which a person has the motivation to follow people's views on the behavior he will do (subjective norms).

c. Perceived behavior control

Perceptions of control are individuals who feel the ease or difficulty in carrying out certain behaviors, or in other words, whether or not there are the necessary resources and opportunities, the individual's perception of the ease or difficulty of carrying out the behavior. Perceptions of behavioral control describe the feelings (self-efficacy) or self-efficacy or individual confidence to perform the behavior.

d. Intention

Intention to do behavior is a person's tendency to choose to do or not to do a behavior. The intention is determined by the extent to which the individual has a positive attitude towards specific behavior and the time to which the individual chooses to do typical behavior and receives support from other influential people in his life.

e. Behavior.

Fisher (2002) states that a person's behavior is controlled by himself and requires control in the availability of resources and opportunities and even specific skills in a person.

\section{Human Intention and Behavior}

The previous description has explained that the Intention in Islamic teachings originates from the hadith and is the basis of one's actions. A human being has confirmed his Intention before he commits a particular act or leaves a specific action. Before a behavior occurs in a person, there has been a psychological dynamic in that person whether he will perform the behavior or not. As Judge alBaidhawi said, psychologically, a person has occurred a thorough consideration process whether he will benefit from his behavior if it is done. He should leave the behavior because he is feared that he will reap risks if done (Faris, 2005).

A sincere intention because of Allah will rely on every human act, both psychologically and religiously, has the following indicators (Luth, 2010): 
1. Allah (God) monitors our work; the meaning is that a person must be embedded in the soul that God constantly monitors everything that someone does. In this psychological review, it is included in the affective domain. This is stated in the hadith about Ihsan. "Worship you as if you saw Allah, and if you can not see Him, be sure if He sees you" (Narrated by Ahmad) (Rajab, 2006).

2. Allah (God) is the goal of our actions, meaning that the driving force of all our behavior (motivation) is to get the pleasure of Allah. Not for anything else, namely the desire to be praised by humans or to get worldly luxuries.

3. Everything that is obtained from work must be grateful and believe that it is the best. Allah has said that if people are thankful for Allah's blessings, Allah will increase His blessings and if they are not grateful, Allah will give them punishment.

4. Everything that is obtained must be used and spent on things that are according to Allah's rules (God).

5. They realize that what is done and obtained, there will be accountability to Allah (God).

\section{Reconstruction of Intention Towards Behavior Change}

Psychological studies of the relationship between Intention and behavior open our eyes that Intention is not just a matter of pronunciation or not in fiqh. However, Intention is a very complex psychological dynamic, so that the actions of believing humans eventually get good luck in the life of this world and the hereafter. To reconstruct the Intention, as stated by Sulaiman al-Asyqar, it takes time and a long process so that someone can control their intentions and desires. Al-Asyqar said that one of the processes that must be passed to reconstruct the Intention successfully is through the strengthening of knowledge. Only with this knowledge can a person's charity (behavior) be of good or bad value. Meanwhile, knowledge can only be obtained through the educational process. Therefore it is also necessary to disclose psychological theories about education (Al-Asyqar, 2010).

Combining the psychological theory of Intention conveyed by Icek Ajzen, which is full of intentions that are influenced by worldly things, and the Islamic view of internal intentions, which are controlled by specific values, it can be seen in the Figure 2 .

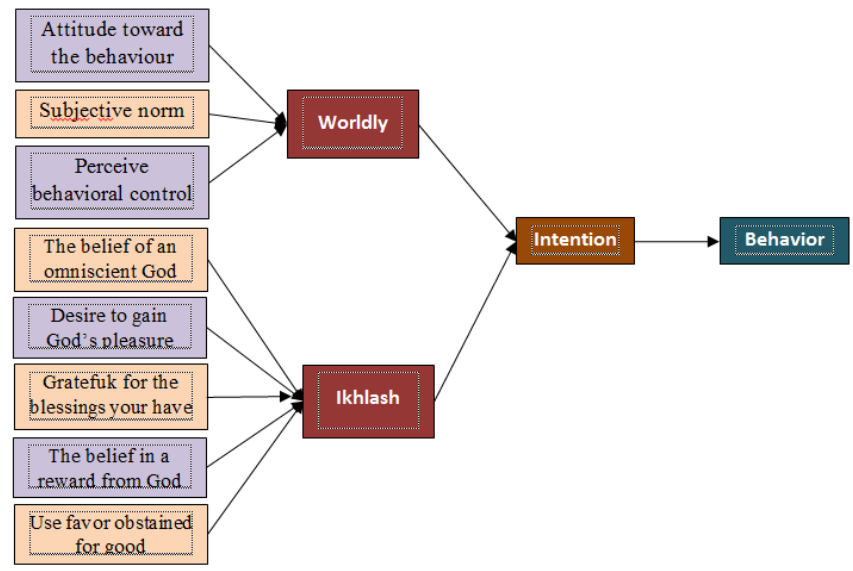

Figure 2. The psychological theory of intention conveyed by Icek Ajzen

The chart in Figure 2 illustrates that that person's intentions influence human actions. The Intention of a person who does an activity is controlled by two things: religious and worldly. Three things affect a person's Intention, namely attitudes toward behavior, subjective norms, and perceptions of behavior control. Ajzen's theory is widely used in research on business behavior and health, where it has been proven that subjective norms greatly influence the intention to do business (Cruz et al., 2015) (Wedayanti \& Giantari, 2016). Meanwhile, the factors that strengthen one's Intention to do something religiously are the belief that God is watching every human behavior, the desire to be pleased with God, the feeling of always being grateful for what is obtained, the belief in Allah's reward, and always using favors for the good that is brought to good things (Al-Qardhawi, 2011). One's belief about God's 
control over human behavior will have an impact on the real way of working. This is because every human being by nature wants to get praise from the supervisor. Doing the work in earnest, because humans want to gain the pleasure of God. Working seriously is a form of gratitude according to Islamic teachings. Working hard means being grateful for what you get. All of this is carried out because of a belief that Allah will reward every human behavior. Therefore, using Allah's favor for good is a major behavior that gives birth to tremendous power and is difficult to predict mathematically (Sentanu, 2018).

From the chart above, psychologically, we can measure how well a person's intentions are in doing work. Whether one's actions are intended for worldly matters only or intended to achieve sincerity, SW'T. In short, he said, the chart above can also be developed in psychological measurement, namely the preparation of a measurement scale for the level of one's sincerity in an act.

\section{Conclusion}

Intention is fundamental in human action. Because all human activities essentially rest on intentions that have the value of devotion to God. The sincere Intention of someone to seek the pleasure of Allah will increase one's strength to do a job. Meanwhile, intentions that are not straight will lead to results that are intended. According to the psychological view, Intention is influenced by three things: attitudes towards control, subjective norms, and perceived behavioral control. From two poles of study, namely psychology and Islam, it is concluded that Intention is influenced by two things, namely worldly elements and religious elements.

\section{Acknowledgments}

Thank you to the friends of the Islamic Religious Education doctoral student UIN Sunan Kalijaga who have provided input and suggestions in discussing this topic. Hopefully, it will become a good deed for all of you. Aamiin.

\section{References}

'Ted, I. D. 2002. Syarbul Arba’ïna Hadiitsan An-Nawawiyah. Yogyakarta: Media Hidayah.

Ajzen, I. 1991. The theory of planned behavior. Organizational Behavior and Human Decision Processes 50(2): 179-211.

Ajzen, I., \& Fishbein, M. 1973) Attitudinal and normative variables as predictors of specific behavior. Journal of Personality and Social Psychology 27(1): 41-57.

Al-Asqalani, I. H. 2008. Fathul Baary. Jakarta: Pustaka Azzam.

Al-Asyqar, U. S. 2010. An-Niyaatu Fil Ibaadah. Depok: Gema Insani Press.

Al-Qardhawi, Y. 2011. Energi Ikblas Agar Hidup Bahagia Dunia-AKhirat. Bandung: Mizania.

Cruz, L. da, Suprapti, N. W. S., \& Yasa, N. N. K. 2015. Aplikasi theory of planned behavior dalam membangkitkan niat berwirausaha bagi mahasiswa Fakultas Ekonomi Unpaz, Dili, Timur Leste. E-Jurnal Ekonomi Dan Bisnis Universitas Udayana 4(12): 895-920.

Faris, A. Q. A. 2005. Tarkiyatun Nafs. Depok: Gema Insani Press.

Idrus, M. 2009. Metode Penelitian Ilmu Sosial Pendekatan Kualitatif dan Kuantitatif. Jakarta: Erlangga.

Luth, T. 2010. Antara Perut dan Etos Kerja dalam Perspektif Islam. Depok: Gema Insani Press.

Purwanto. 2010. Instrumen Penelitian Sosial dan Pendidikan, Pengembangan dan Pemanfaatan. Yogyakarta: Pustaka Pelajar.

Rajab, I. 2006. Jamiul Ulum wal Hikam fi Syarbi Hadits Sayyidil Arab wal Ajm. Jakarta: Darul Ulum.

Sentanu, E. 2018 Quantum Ikhlas. Jakarta: Gramedia.

Sulaeman, E. S. 2016. Pembelajaran Model Perilaku Kesehatan, Konsep dan Aplikasi. Surakarta: UNS Press.

Wedayanti, N., \& Giantari, I. 2016) Peran pendidikan kewirausahaan dalam memediasi pengaruh norma subyektif terhadap niat berwirausaha. E-Jurnal Manajemen Universitas Udayana 5(1): 533-560 